\title{
USING HIGH-FREQUENCY ACCELEROMETER TO DETECT MACHINE TILT
}

\author{
Alberto Cadei ${ }^{1}$, Omar Mologni ${ }^{2}$, Andrea Rosario Proto ${ }^{3}$, Gaetano D`Anna ${ }^{2}$, Stefano Grigolato ${ }^{1}$ \\ ${ }^{1}$ University of Padova, Italy; ${ }^{2}$ University of British Columbia, Canada; \\ ${ }^{3}$ Mediterranean University of Reggio Calabria, Italy \\ alberto.cadei@studenti.unipd.it,omar.mologni@ubc.ca, andrea.proto@unirc.it, \\ gaetano.danna@studenti.unipd.it, stefano.grigolato@unipd.it
}

\begin{abstract}
The use of full-mechanized harvesting systems is limited by terrain factors, such as very steep slopes and roughness terrain. Focusing on salvage logging conditions, forest operations are characterized by high costs and reduced productivity, as well as in terms of safety. This work aims to identify and compare the relation between the machine tilt and ground slope and the effect in different harvesters and forwarders, based on the technology and type of machine. In particular, the machines involved in this study are a harvester and forwarder working in the specific condition of salvage logging in windthrow areas. High-frequency 3-axis accelerometers and a GNSS sensor were used to monitoring in continuous tilt and motion of the machines. From the position detected by the GNSS sensor, the ground slope was obtained. The results report that the correlation between the machine tilt and ground slope depends on the type of the machine and technology. The high-frequency 3-axis accelerometer results are affordable to detect an accurate machine tilt showing the possibility to use the combination of different low-cost sensors to analyze the operation condition of forest machines in complex terrain.
\end{abstract}

Keywords: accelerometer, harvester, forwarder, wind throw, forest operations.

\section{Introduction}

Forests cover over $43 \%$ of the European Union land area $\left(1.82 \cdot 10^{6} \mathrm{~km}^{2}\right)$ [1]. Because of the increase of forest biotic and abiotic disturbances (e.g. bark beetle outbreaks, wildfires and wind storms) in the last years [2;3], the frequency of hazards to the operators when working in salvage logging conditions could increase [4]. When salvage logging is appropriate to be applied, the most suitable technological solutions are those based on fully mechanized systems as these guarantee high productivity and above all a lower risk for operators as they work exclusively on the machines [5-7].

Harvesting operations in steep terrain were characterized by chainsaw felling, followed by cable yarding extraction using choker-setters [8]. According to [9], specialized harvesting machines with special undercarriages and carriers can reach safely slope terrain up to $70 \%$ without external support. To improve stability in steep terrain and ensure the comfort of the operator, self-levelling of the cabin and crane have been introduced in forestry machines with tracked undercarriage [10]. Wheeled machines use other solutions in order to change the position of the centre of gravity and increase stability. A typical solution is to increase the numbers of wheels and group in tandem (bogie) to reduce machine inclination and make easier to overcome small obstacles in the case of passive bogie $[10 ; 11]$. Wheeled harvesting machines can also be equipped with additional hydraulic cylinders on the driven arms and operators can manually adjust the machine inclination ad overcome uneven terrain (e.g. ditches, stumps or stones) while tracked harvesting machines, in particular half-track, with independent suspension system can improve the stability in rough or steep terrain [12]. A wheeled harvester, Valmet 911 Snake harvester, was adapted for the specific purpose of felling in steep terrain in [11], where the standard wheels were replaced with four trapezoidal track. The improvement allows the machine to operate at slope limitation until $70 \%$.

In the last few decades, the development of machine performance allowed the machine to extend the slope limitations until 75-85\% [13]. For example, the introduction of synchronized winch with wheels and self-levelling boom and cabin are the most important introduction that allowed the machine to expand the fully mechanized ground-based harvesting system [12-14]. The introduction of these developments implied an increase in power and weight and, as a consequence, the impact on soil and stand conditions $[15 ; 16]$. Larger-sized machines are necessary for storm damaged areas compared with normal conditions and operator training is also required to reduce risks for forest operators for example, harvesters in steep terrain and in salvage logging operations need to work in the direction of the main slope, in slope over $25 \%$ [17]. 
The objectives of the present study are to identify the relation between the forest machine tilt and ground slope during salvage logging operation and to evaluate the efficiency of machines levelling in different terrain slopes.

\section{Materials and methods}

A total of five forest machines, three forwarders (F1, F2 and F3) and two harvesters (H1 and H2) were involved in this study (Table 1, Table 2). F3 used synchronized winch during timber extraction.

The data collection was based on a time and motion study through video recording using on-board digital video cameras (Drift ${ }^{\circledR}$, Ghost-HD), as proposed by $[18 ; 19]$. The machine position was collected using a GNSS receiver (Garmin ${ }^{\circledR}$ 64S) located inside the cabin. For better reception, the GNSS was integrated with an external magnetic antenna (Garmin ${ }^{\circledR}$ 25MCX) located outside the cabin. Both the video cameras and the GNSS receiver were powered with a $20000 \mathrm{mAh}$ power bank. Machine tilt was detected using an MSR $^{\circledR} 145$ high-frequency three-axis accelerometer installed on the chassis of the machines (data acquisition set at $25 \mathrm{~Hz}$ ) and powered by its autonomous battery. Dedicated R code was developed in order to resample the different resolution of the DTM (1 m and $2.5 \mathrm{~m}$ ) to the same resolution of $5 \mathrm{~m}$ cells adjacent using bilinear interpolation. Machine position collected from GNSS receiver was filtered applying a filter of $5 \mathrm{~m}$ for forwarders and $3 \mathrm{~m}$ for harvesters. Machine tilt was determined by the accelerometer data through a specific code developed in $\mathrm{R}$ studio software, with a resolution of $1 \mathrm{~Hz}$. According to [20], in order to reduce the effect of the machine vibration (e.g. short term extreme tilting), a running of five-points average $(5 \mathrm{~s})$ was applied for estimate the machine tilt in percentage. Any delay time identified by the time and motion study was excluded from the dataset.

Each machine was analysed in terms of tilt and the terrain slope at the same location of the machine. The terrain slope was classified according to the National Terrain Classification NTC [21] (Table 3). The difference between estimated machine tilt and terrain slope from DTM in percentage (GST) was added to the machine dataset.

A two-way ANOVA was used to investigate the main effects of two independent factor variables (terrain slope classification and type of machine) and the effect of the interaction of the independent variables on the GST. For each machine, linear regression was used to test the relationship of the GST to the slope classification and type of machine, with the level of significance set to 0.05 . Least-Square Means was used to evaluate the interaction between the independent variables as a prediction from the linear model.

Table 1

Forwarder specification

\begin{tabular}{|c|c|c|c|c|}
\hline Machine & Units & F1 & F2 & F3 \\
\hline Location & - & Passo Vezzena (TN) & Redagno di sopra (BZ) & Nevegal (BL) \\
\hline Power & $\mathrm{kW}$ & 136 & 129 & 210 \\
\hline Wheel number & $\mathrm{n}^{\mathbf{o}}$ & 8 & 8 & 8 \\
\hline Steering angle & ${ }^{\mathrm{o}}$ & 44 & 40 & 44 \\
\hline Weight empty & $\mathrm{t}$ & 18.1 & 17 & 19.8 \\
\hline Load capacity & $\mathrm{t}$ & 13 & 14 & 15 \\
\hline Tire size & - & $710 / 45-26.5$ & $710 / 45-26.5$ & $710 / 45-26.5$ \\
\hline Gross lifting torque & $\mathrm{kNm}$ & 125 & 76 & 140 \\
\hline $\begin{array}{c}\text { Maximum boom } \\
\text { reach }\end{array}$ & $\mathrm{m}$ & 10.0 & 8.4 & 10.0 \\
\hline Bogie & - & ${ }^{1} \mathrm{~PB}+\mathrm{BS}+\mathrm{DF}$ & ${ }^{2} \mathrm{BS}+\mathrm{DF}$ & ${ }^{2} \mathrm{BS}+\mathrm{DF}$ \\
\hline Cabin & - & ${ }^{3} \mathrm{SL}+\mathrm{R}$ & - & - \\
\hline Level crane & - & Yes & No & Yes \\
\hline
\end{tabular}

1 - Portal bogie axle with balancing system and differential lock; 2 - Balancing system with differential lock; 3 - Self-levelling and rotating 
Harvester specification

\begin{tabular}{|c|c|c|c|}
\hline Machine & Units & H1 & H2 \\
\hline Location & - & Redagno di sopra (BZ) & Passo Vezzena (TN) \\
\hline Power & $\mathrm{kW}(\mathrm{hp})$ & $240(325)$ & $193(259)$ \\
\hline Wheel number & $\mathrm{n}^{\mathbf{o}}$ & 6 & 6 \\
\hline Steering angle & $\mathrm{o}^{-}$ & 44 & 40 \\
\hline Weight & $\mathrm{t}$ & 27.0 & 19.4 \\
\hline Front tire size & - & $650 / 60-26.5$ & $600 / 55-26.5$ \\
\hline Rear tire size & - & $700 / 70-34$ & $600 / 65-34$ \\
\hline Gross lifting torque & $\mathrm{kNm}$ & 310.0 & 225.3 \\
\hline Maximum boom reach & $\mathrm{m}$ & 11.5 & 10.0 \\
\hline Front axles & - & ${ }^{1} \mathrm{BB}+\mathrm{HPA}+\mathrm{DL}$ & ${ }^{2} \mathrm{~B}+\mathrm{DL}$ \\
\hline Rear axle & - & ${ }^{3} \mathrm{HC}+\mathrm{DL}$ & ${ }^{4} \mathrm{HSA}+\mathrm{DL}$ \\
\hline Cabin & - & ${ }^{5} \mathrm{SL}+\mathrm{R}$ & ${ }^{5} \mathrm{SL}+\mathrm{R}$ \\
\hline
\end{tabular}

1 - Balanced bogie with hydraulic pendulum arms, mechanic differential lock; 2 - Bogie and mechanic differential lock; 3 - Axle equipped with hydraulic cylinder with differential lock; 4 - Hydraulic swing axle with differential lock; 5 - Self-levelling and rotating

Terrain slope classification

Table 3

\begin{tabular}{|c|c|}
\hline Slope range, \% & Designation \\
\hline$<11$ & Level \\
\hline $11-20$ & Gentle \\
\hline $20-30$ & Moderate \\
\hline $30-35$ & Steep 1 \\
\hline $35-40$ & Steep 2 \\
\hline $40-50$ & Steep 3 \\
\hline$>50$ & Very steep \\
\hline
\end{tabular}

\section{Results and discussion}

The total number of sample points was 188323 for forwarder groped machines and 109166 sample points for harvester grouped machines (Table 4). The difference between the machine tilt and ground slope was different for each machine. In particular, the $\mathrm{H} 1$ shows a positive average difference of $9 \%$, while $\mathrm{H} 2$ shows a negative difference of $9 \%$. In addition, the estimated machine tilt exceeded ground slope in all machines involved in this study, except for $\mathrm{H} 2$.

Table 4

Descriptive statistics of machine tilt and terrain slope

\begin{tabular}{|c|c|c|c|c|c|c|c|c|}
\hline \multirow{2}{*}{ Machine } & \multirow{2}{*}{$\boldsymbol{N}$} & \multicolumn{3}{|c|}{ Machine tilt, } & \multicolumn{3}{c|}{ Terrain slope, } & \multirow{2}{*}{ Difference, } \\
\cline { 3 - 9 } & & $\begin{array}{c}5 \text { th } \\
\text { percentile }\end{array}$ & Mean & $\begin{array}{c}\text { 95th } \\
\text { percentile }\end{array}$ & $\begin{array}{c}5 \text { th } \\
\text { percentile }\end{array}$ & Mean & $\begin{array}{c}\text { 95th } \\
\text { percentile }\end{array}$ & \% \\
\hline F1 & 35106 & 9.73 & 21.00 & 37.37 & 2.72 & 16.02 & 35.76 & 4.98 \\
\hline F2 & 76539 & 12.35 & 29.58 & 52.07 & 10.75 & 24.42 & 36.36 & 5.16 \\
\hline F3 & 76678 & 18.72 & 37.68 & 61.16 & 22.69 & 33.94 & 52.16 & 3.74 \\
\hline H1 & 44807 & 7.30 & 31.83 & 49.99 & 11.15 & 23.27 & 37.52 & 8.56 \\
\hline H2 & 64359 & 7.34 & 21.56 & 40.18 & 19.25 & 30.52 & 47.19 & -8.89 \\
\hline
\end{tabular}




\section{Forwarder}

The linear model shows statistical differences between forwarders and between GST and terrain slope classification among the same forwarders. F3 in level terrain report a low correlation with GST, with an adjusted $\mathrm{R}^{2}$ explaining the $38 \%$ of the GST variation $(F=5690 ; p<0.01)$.

As it is shown in Fig.1, F3 faced a wide range of ground slope. Furthermore, the effect of ground slope had lowered influence on machine tilt in very steep terrain (slope over $50 \%$ ). The technology of the machine could explain the extreme ground slope faced during the forwarding operation of F3, and in particular, the use of the winch assist technology.

In Fig. 2 is shown the effect of the terrain steepness on the forwarders tilt. In level and gentle terrain (slope less than $20 \%$ ), all the machines adjust and increase machine inclination, with respect to the terrain slope. Machine tilt was higher than ground slope, probably due to the presence of obstacles along the corridors (e.g. stumps or stones) and working elements (e.g. loading phases). In moderate terrain slope, the machines show different types of behaviour, with GST of $-4 \%, 7 \%$ and $15 \%$ respectively for F1, F2 and F3. Furthermore, GST of F1 in steep 1 terrain was similar to GST in moderate terrain. In steep 2 only F3 machine tilt was similar to ground slope (-1 \% GST). This means that the technology of F3 forwarder allowed to work in moderate terrain slope without particular positioning of the machine to reduce the machine tilt and increase the machine stability. In steep 3 terrain forwarders working with a GST from $-8 \%$ to $-14 \%$. According to Fig. 1, 479 data, recorded at $1 \mathrm{~Hz}$, were detected for F1, while 2,009 and 10,240 data were recorded for F2 and F3. In very steep terrain, GST for F1 and F3 forwarders were respectively $-30 \%$ and $-28 \%$ while GST for F2 was $16 \%$. Although F3 worked in very steep terrain for $13 \%$ of total time working (Fig. 1), F3 adjusted the machine tilt of $28 \%$, with respect to terrain slope.

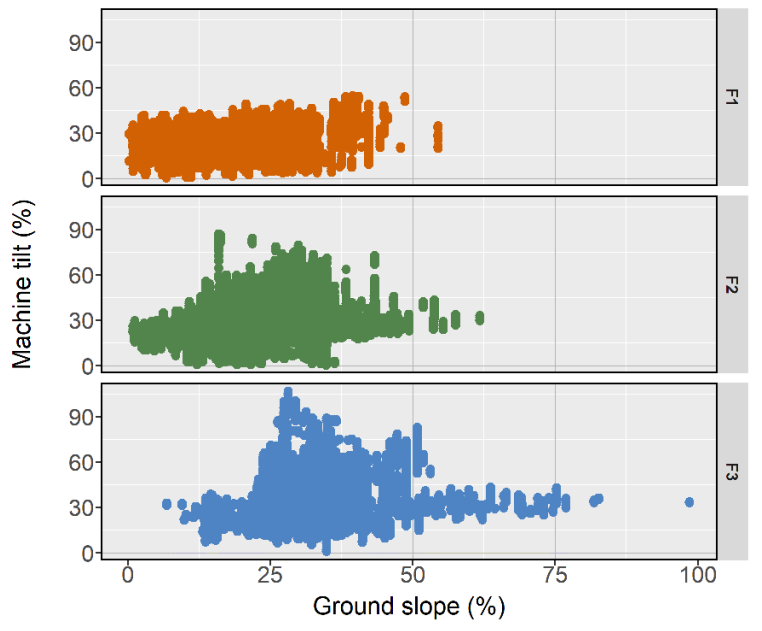

Fig. 1. Distribution of forwarder tilt and ground slope

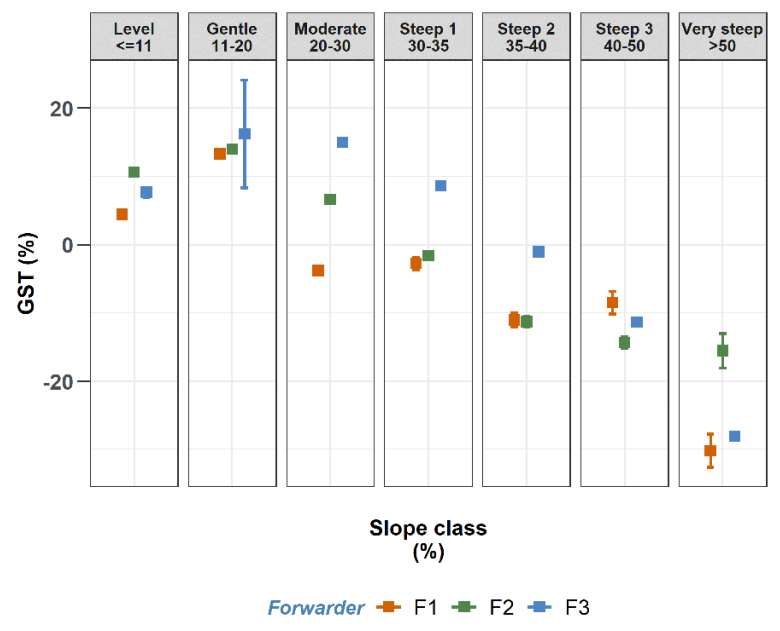

Fig. 2. Least square means of linear model

\section{Harvester}

The linear model shows statistical differences between harvesters and between GST and terrain slope classification. $\mathrm{H} 2$ in level terrain does not show a significant correlation with GST, due to the small amount of observation (48). However, the adjusted $R^{2}$ explains the $54 \%$ of the GST variation $(F=9863 ; p<0.01)$.

Fig.4 shows the effect of the terrain steepness on the forwarder tilt. In level and moderate terrain, H1 working without manually machine levelling and machine tilt was slightly similar to the ground slope (GST $2 \%$ and $-2 \%$ respectively). When the terrain slope increases up to $50 \%, \mathrm{H} 1$ harvester, equipped with balanced bogie with hydraulic pendulum arms and axles equipped with hydraulic cylinder, was able to adjust the machine tilt, with the respect of ground slope, from a GST of $-9 \%$ in steep 1 terrain, to $-23 \%$ in steep 3 terrain. $\mathrm{H} 2$ harvester, equipped with bogie and hydraulic swing axle, working in steep terrain from ground slope of $30 \%$ to $50 \%$ with a GST from $2 \%$ to $-3 \%$ 
respectively. Over $50 \%$ of ground slope, in very steep terrain $\mathrm{H} 1$ level the machine tilt of $-37 \%$, while $\mathrm{H} 2$ working with machine tilt lower than $24 \%$ compared to ground slope. As illustrated by Fig. $1, \mathrm{H} 2$ faced a wide range of ground slope, but over $50 \%$ of ground slope only 75 data recorded at 1 $\mathrm{Hz}$ were detected.

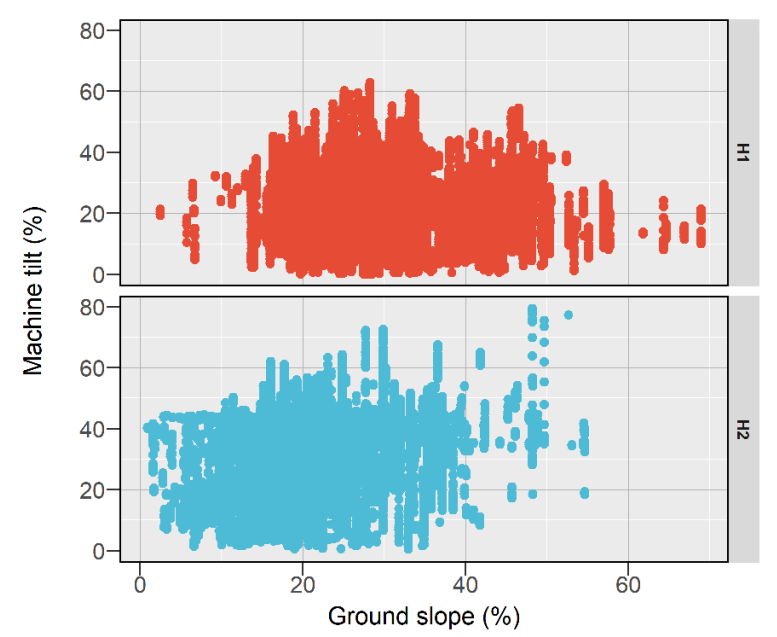

Fig. 3. Distribution of harvester tilt and ground slope

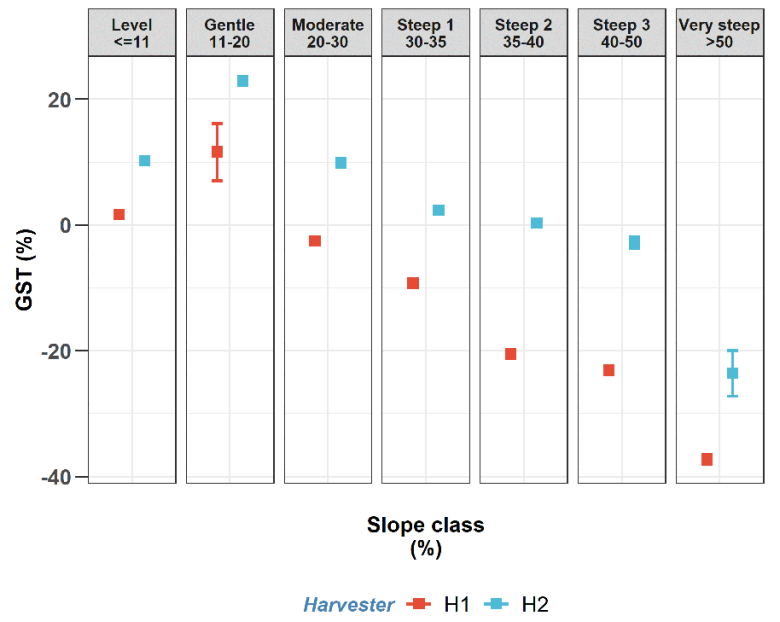

Fig. 4. Least square means of linear model

\section{Conclusions}

This study, based on three forwarders and two harvesters under real working conditions, shows the effect of the ground slope on the machine tilt. Winch assisted forwarder equipped with a balancing system, differential lock and crane level can work in a wide range of ground slope and, over ground slope of $50 \%$ could reduce the machine tilt of $28 \%$. Harvester equipped with balanced bogie with hydraulic pendulum arms and axles equipped with a hydraulic cylinder could reduce the machine tilt of $37 \%$ in slope over $50 \%$.

However, the methodology adopted in this research, both in the field study and in the data analysis, shows great potential. This research needs to be done over a longer time period to collect a large amount of data and, using GIS-based analysis, geo-referenced information could be used to identify critical harvesting areas and preferred corridors to operate safely in steep terrain.

\section{Acknowledgments}

This study is part of the Young research for VAIA of the PhD LERH Program of the Università degli Studi di Padova in the frame of VAIA-Front project of TESAF Department.

\section{References}

[1] Coyette H., Schenk C. Agriculture, Forestry and Fishery Statistics. Eurostat, Luxemburg 2019, DOI: $10.2785 / 45595$.

[2] Seidl R, Schelhaas M-J, Rammer W, Verkerk P J. Increasing forest disturbances in Europe and their impact on carbon storage. Nature Climate Change, vol. 4, 2014, pp. 806, DOI: $10.1038 /$ nclimate2318.

[3] Lindner M, Maroschek M, Netherer S, Kremer A, Barbati A, Garcia-Gonzalo J, Seidl R, Delzon S, Corona P, Kolström M, Lexer M J, Marchetti M. Climate change impacts, adaptive capacity, and vulnerability of European forest ecosystems. Forest Ecology and Management, vol. 259, 2010, pp. 698-709, DOI: 10.1016/j.foreco.2009.09.023.

[4] Sullman M J M, Kirk P M. Harvesting Wind Damaged Trees: A Study of the Safety Implications for Fallers and Choker Setters. International Journal of Forest Engineering , vol. 12, 2001, pp. 6777, DOI: 10.1080/14942119.2001.10702448. 
[5] Kärhä K, Anttonen T, Poikela A, Palander T, Laur A. Evaluation of Salvage Logging Productivity and Costs in Windthrown Norway Spruce-Dominated Forests. Forests, vol. 9, 2018, pp. 280, DOI: 10.3390/f9050280.

[6] Enache A, Kühmaier M, Visser R, Stampfer K. Forestry operations in the European mountains: a study of current practices and efficiency gaps. Scandinavian Journal of Forest Research , vol. 31, 2016, pp. 412-427, DOI: 10.1080/02827581.2015.1130849.

[7] Magagnotti N, Picchi G, Spinelli R. A versatile machine system for salvaging small-scale forest windthrow. Biosystems Engineering, vol. 115, 2013, pp. 381-388, DOI: 10.1016/j.biosystemseng.2013.05.003.

[8] Visser R, Raymond K, Harrill H. Mechanising steep terrain harvesting operations. New Zealand Journal of Forestry, vol. 59, 2014, pp. 3-8.

[9] Cavalli R. Conference CROJFE $2015 »$ Forest Engineering - Current Situation and Future Challenges «. Zagreb, March 18-20 2015, pp. 1-3.

[10] Jodłowski K, Kalinowski M. Current possibilities of mechanized logging in mountain areas. Forest Research Papers, vol. 79, 2018, pp. 365-375, DOI: 10.2478/frp-2018-0037.

[11] Berkett H. An Examination of the Current Slope Gradients Being Experienced by Ground- Based Forest Machines in New Zealand Plantation Forests, University of Canterbury, 2012.

[12] Mologni O, Grigolato S, Cavalli R. Harvesting systems for steep terrain in the Italian alps: State of the art and future prospects. Contemporary Engineering Sciences , vol. 9, 2016, pp. 1229-1242, DOI: 10.12988/ces.2016.68137.

[13] Visser R, Stampfer K. Expanding ground-based harvesting onto steep terrain: A review. Croatian Journal of Forest Engineering, vol. 36, 2015, pp. 321-331.

[14] Cavalli R, Amishev D, Steep terrain forest operations - challenges, technology development, current implementation, and future opportunities. International Journal of Forest Engineering , vol. 30, 2019, pp. 175-181, DOI: 10.1080/14942119.2019.1603030.

[15] Cambi M, Certini G, Neri F, Marchi E. The impact of heavy traffic on forest soils: A review Martina. Forest Ecology and Management, vol. 338, 2015, pp. 124-138, DOI: 10.1016/j.foreco.2014.11.022.

[16] Garren A M, Bolding M C, Aust W M, Moura A C, Barrett S M. Soil Disturbance Effects from Tethered Forwarding on Steep Slopes in Brazilian Eucalyptus Plantations. Forests, vol. 10, 2019, pp. 21, DOI: 10.3390/f10090721.

[17]CTBA. Technical Guide on Harvesting and Conservation of Storm Damaged Timber. Paris (France) 2004.

[18] Grigolato S, Panizza S, Pellegrini M, Ackerman P, Cavalli R. Light-lift helicopter logging operations in the Italian Alps: a preliminary study based on GNSS and a video camera system. Forest Science and Technology, vol. 12, 2016, pp. 88-97, DOI: 10.1080/21580103.2015.1075436.

[19] Cadei A, Mologni O, Röser D, Cavalli R, Grigolato S. Forwarder Productivity in Salvage Logging Operations in Difficult Terrain. Forests 2020, vol. 11, 2020, pp. 14, DOI: $10.3390 / \mathrm{F} 11030341$.

[20] Visser R, Berkett H. Effect of terrain steepness on machine slope when harvesting. International Journal of Forest Engineering, vol. 26, 2015, pp. 1-9, DOI: 10.1080/14942119.2015.1033211.

[21] Erasmus D. National Terrain Classification System for Forestry. Pietermaritzburg, South Africa 1994. 